\title{
Population structure of the endangered tree fern Cyathea praecincta (Cyatheaceae), endemic of the Brazilian Atlantic Forest
}

\author{
Mayara Magna Silva, Rafael de Paiva Farias, Lucas Erickson Nascimento da Costa \& Iva Carneiro Leão Barros
}

Universidade Federal de Pernambuco, Programa de Pós Graduação em Biologia

Vegetal, Av. Prof. Moraes Rego, 1235, CEP 50670-901, Recife, Pernambuco. mayarammallet@gmail

Received on 28.IX.2016

Accepted on 27.XI.2017

DOI 10.21826/2446-8231201772312

\begin{abstract}
This study aimed to determine the population structure of Cyathea praecincta (Kunze) Domin in an Atlantic Forest fragment in Northeastern Brazil. Individuals of C. praecincta were recorded inside $1800 \mathrm{~m}^{2}$ of interior forest area. Caudex height was measured in order to classify specimens into length classes and relate this variable with fertility of individuals. Ninety-eight individuals were sampled, featuring a low population density $\left(5.4\right.$ individuals per $\left.100 \mathrm{~m}^{-2}\right)$ when compared to other tree fern populations. The spatial distribution was clustered $(\mathrm{Ia}=2.12$; $\mathrm{p}=0.0002)$ and the length class distribution followed an exponential or reverse J-shaped pattern. The high number of individuals classified in the smaller length class ( 0 to $0.25 \mathrm{~m}$ ) may be an indication that the studied population is under expansion. This endorses the need for conservation of the study area and for reducing the risk of local extinction by disturbances.
\end{abstract}

Keywords: arborescent, caudex length, aggregated distribution

RESUMO - Estrutura populacional da samambaia arborescente ameaçada Cyathea praecincta (Cyatheaceae), endêmica da Floresta Atlântica Brasileira. Este estudo teve como objetivo determinar a estrutura populacional de Cyathea praecincta (Kunze) Domin em área de Floresta Atlântica no Nordeste do Brasil. Indivíduos de C. praecincta foram contabilizados em uma área de $1800 \mathrm{~m}^{2}$ do interior florestal. A altura do cáudice foi mensurada para classificar espécimes em classes de altura e relacionar esta variável com a fertilidade dos indivíduos. Foram amostrados 98 indivíduos, apresentando uma baixa densidade (5.4 indivíduos por $100 \mathrm{~m}^{-2}$ ), quando comparada a outras populações de samambaias arborescentes. A distribuição espacial foi agregada $(\mathrm{Ia}=2.12 ; \mathrm{p}=0.0002)$ e a distribuição por classes de altura seguiu o padrão exponencial ou J-invertido. $\mathrm{O}$ alto número de indivíduos em classes de menor altura $(0$ a $0.25 \mathrm{~m})$ pode ser um indicativo que a população estudada está em expansão. Assim, se reforça a necessidade de conservação da área de estudo em prol de reduzir os riscos de extinção local por distúrbios.

Palavras-chaves: arborescentes, altura do cáudice, distribuição agregada

\section{INTRODUCTION}

Investigating the natural population structure, i.e. density, spatial distribution, and age class classification (Ricklefs 2003, Gurevitch et al. 2009), represents the fastest way to evaluate the status of a population on a particular location (Peters 1994). This information allows formulating hypotheses on the processes that shape population structure (Dale 1999) as well as sheds light on key aspects such as how habitat exploitation (Oliveira et al. 1989) and population regeneration (Clark 1994) has taken place in the area.

The understanding of how populations are structured on a natural space must be a prerequisite for the development of conservation strategies, especially in the case of threatened species (Krishna et al. 2009). For example, the survey on the population structure and preferential habitats of Cyathea cunninghamii Hook.f. and Cyathea $\mathrm{x}$ marcescens N.A Wakef. in Australia carried out by Peacock et al. (2013) provided fundamental information for the elaboration of the management and conservation plan of these species.
In the present study, we surveyed a population of Cyathea praecincta (Kunze) Domin (Cyatheaceae). This tree fern is endemic to the Brazilian Atlantic Forest, occurring from the northeast state of Pernambuco to the southern state of Santa Catarina (Windisch \& Santiago 2015), and is classified as a vulnerable species according to the IUCN criteria (Weigand $\&$ Lehnert 2016). This species has only rarely been recorded in inventories carried out in Northeastern Atlantic Forest (e.g. Pietrobom \& Barros 2007, Silva et al. 2011, Pereira et al. 2013), which represents the most fragmented and unknown biogeographical unit of this biome, and with the highest number of endemic and/or endangered species populations (Rodrigues et al. 2004) outside protected areas (Ranta et al. 1998, Uchôa-Neto 2002).

Studies involving $C$. praecincta usually present floristic data and only brief information on the species ecology, precisely its preference for forest interior and less anthropized environments (Pietrobom \& Barros 2007, Pereira et al. 2013). In this context, this study aimed to increase the knowledge on the ecology of $C$. praecincta by analyzing the population structure of the species, including 
information on the population spatial distribution and density.

\section{MATERIAL AND METHODS}

\section{Study site}

The study was performed in a Northeastern Atlantic Forest (NAF) fragment known as "Mata do Tauá" $\left(08^{\circ} 35^{\prime} 50^{\prime \prime} \mathrm{S}\right.$ and $\left.35^{\circ} 10^{\prime} 02^{\prime \prime} \mathrm{W}\right)$, with approximately 280 ha of dense rain forest vegetation, located in the municipality of Sirinhaém, Pernambuco, Northeastern of Brazil. The climate in the area is hot and wet (As) with a short dry season (October to December, $<60 \mathrm{~mm}$ ), average annual temperature of $24^{\circ} \mathrm{C}$ and annual rainfall of $2100 \mathrm{~mm}$ (Climate-Data.Org 2016). The site is not an official Conservation Unit, but the management of the Mill responsible for the area (Trapiche Mill) controls and monitors the use of the forest.

\section{Field work and data analysis}

Seventy-two contiguous $25 \mathrm{~m}^{2}(5 \times 5 \mathrm{~m})$ plots were established inside a total area of $1800 \mathrm{~m}^{2}(60 \times 30 \mathrm{~m})$ where the species occurred inside the forest, including moist slopes close to watercourses. The number of $C$. praecincta individuals per plot, the presence of fertile leaves and the caudex length of these individuals were recorded. In this study, each erect caudex with a crown of fronds was recognized as an individual and underground connections between caudices were not considered. The above-ground portion of caudices was considered in measurements. Partially exposed caudices (i.e. partially covered by soil) were assigned to the smaller length class. Fertility rate was based on the number of individuals with fertile leaves. Population density was determined based on the average number of individuals per $100 \mathrm{~m} 2$, according to the criteria employed by Schmitt \& Windisch (2005). The spatial distribution pattern was determined through the Aggregate Index (Ia) proposed by Perry et al. (1998), which characterizes three patterns: (I) clustered, when values are higher than 1; (II) regular, when values are lower than 1; and (III) random, when values are equal to 1. This index was computed in the SADIEShell software (Perry et al. 1998).

The area of occurrence of the population was mapped using Cartesian coordinates (X and $\mathrm{Y}$ ) and each plot was described considering its spatial position. This analysis was performed in the SADIEShell software (Perry et al. 1998).

Individuals were classified into height interval classes determined by Tanner (1983) for tree fern species, with adaptations, as follow: 0 to $0.25 \mathrm{~m}$ (Class 1$),>0.25$ to $0.5 \mathrm{~m}$ (Class 2), $>0.5$ to $0.75 \mathrm{~m}$ (Class 3 ), $>0.75$ to 1.0 $\mathrm{m}$ (Class 4$),>1.0$ to $1.25 \mathrm{~m}$ (Class 5$),>1.25$ to $1.5 \mathrm{~m}$ (Class 6), $>1.5$ to $1.75 \mathrm{~m}$ (Class 7) and $>1.75 \mathrm{~m}$ (Class 8).

To analyze the relationship between caudex height and fertility of individuals, a logistic regression was carried out using the software Statistica 7.0 (StatSoft 2002). For all tests, the significance level adopted was $\mathrm{p} \leq 0.05$.

\section{RESULTS}

Among the 98 C. praecincta individuals sampled, 72 were sterile, corresponding to 5.4 individuals per $100 \mathrm{~m}^{2}$. The longer caudex recorded was $1.98 \mathrm{~m}$ and 46 individuals had non-exposed caudices, with leaves emerging almost directly from the ground. There was no record of individuals in more than $50 \%$ of the plots (46) and the highest number of individuals per plot was 18 . The population showed a highly clustered spatial distribution pattern $(\mathrm{Ia}=2.12 ; \mathrm{p}$ $<0.001$ ) (Fig. 1).

Most individuals (68\%) had small caudex length, classified in the shortest category, the class one (Fig. 2). Only one individual had the largest length, in the class eight (Fig. 2). The fertility rate was positively related to caudex length $\left(\chi^{2}=41.5245 ; \mathrm{df}=1 ; \mathrm{p}<0.001\right)$, although three fertile plants (with 5,10 and $15 \mathrm{~cm}$ ) were classified in the smaller length class.

\section{DISCUSSION}

The C. praecincta population studied had low density when compared to other Cyatheaceae species. For example, densities of 17.4 and 11.5 individuals per 100 $\mathrm{m}^{2}$ have been recorded for Alsophila setosa Kaulf. and C. delgadii Sternb., respectively, in southern Atlantic Forest (Schmitt \& Windisch 2005, 2007, respectively), and 12.9 individuals per $100 \mathrm{~m}^{2}$ for $C$. delgadii in the Brazilian Cerrado (Lehn \& Resende 2007). This can be a reflection of the different conservation states of the Southern and Northeastern Atlantic Forest. The NAF has a history of intense anthropogenic disturbance, so that most of the forest remnants are small and isolated (Ranta et al. 1998). This can influence the density of plant populations (Young et al. 1996). In fact, large populations of Cyatheaceae species in NAF fragments are rare (Iva Barros, unpublished data), and this is linked to the land use dynamics.

The clustered distribution found in the studied C. praecincta population is typical of Cyatheaceae (Arens \& Baracaldo 1998, Schmitt \& Windisch 2005, 2007, Lehn \& Resende 2007, Jones et al. 2007) and herbaceous ferns (Mallmann et al. 2013). This pattern can be a result of fern spore dispersion, where most of the spores land close to the parent plant (Wolf et al. 2001), or a result of vegetative reproduction, as reported in other Cyatheaceae (e.g. Schmitt \& Windisch 2005, Lehn \& Resende 2007), and/or microhabitat spatial arrangement, which may have influenced the high number of plots without $C$. praecincta individuals in the present study. Some microhabitats do not favor the occurrence of the species, like highly wet soils (close to watercourses) that offer little stability for caudex fixation. Furthermore, strong dominance of angiosperms in some spots may also lead to absence of C. praecincta individuals, either by hampering spore germination or by prompting intense competition for resources.

The high proportion of individuals on the smaller height classes observed in the present $C$. praecincta population has 
A

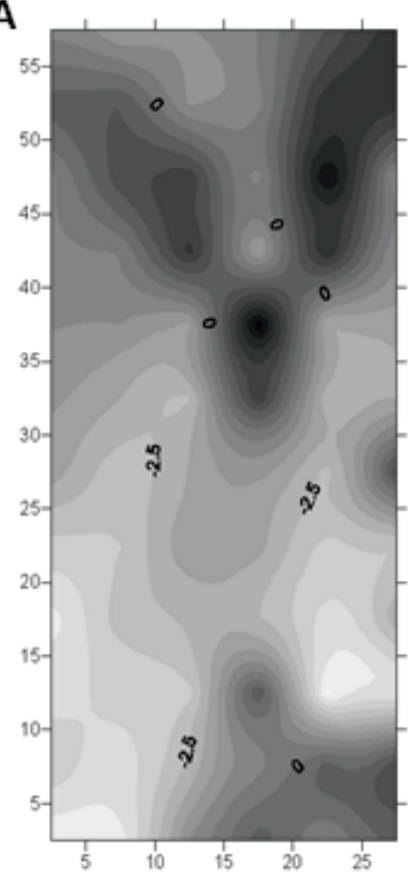

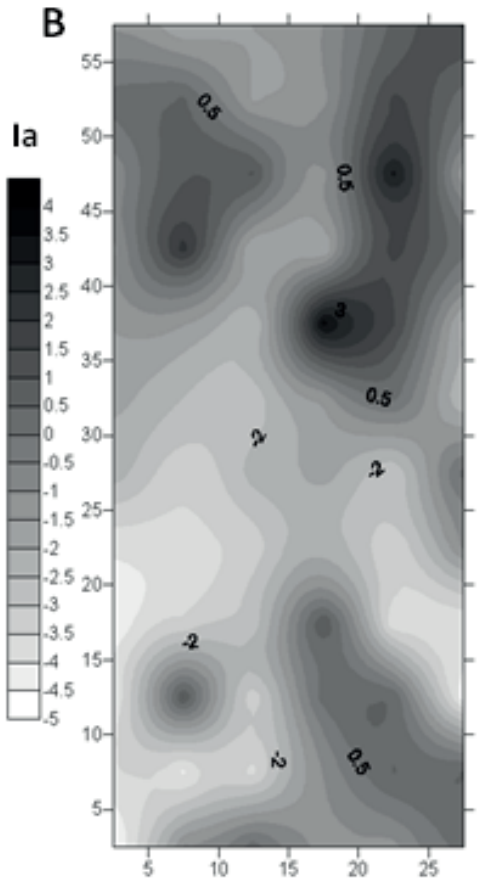

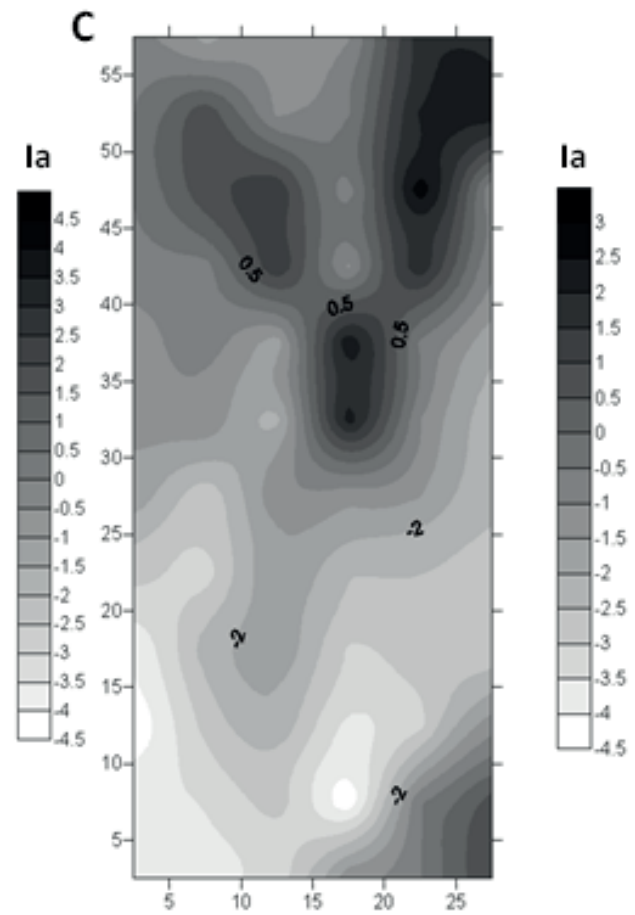

Figs. 1 A-C. Spatial distribution of Cyathea praecincta in an Atlantic Forest fragment in Northeastern Brazil. A. Total individuals sampled within $25 \mathrm{~m}^{2}$; B. Spatial distribution of sterile $C$. praecincta individuals within $25 \mathrm{~m}^{2}$; C. Spatial distribution of fertile of $C$. praecincta individuals within $25 \mathrm{~m}^{2}$. Ia $=$ Aggregation index; the highly clustered pattern in the population is represented by the black patches.

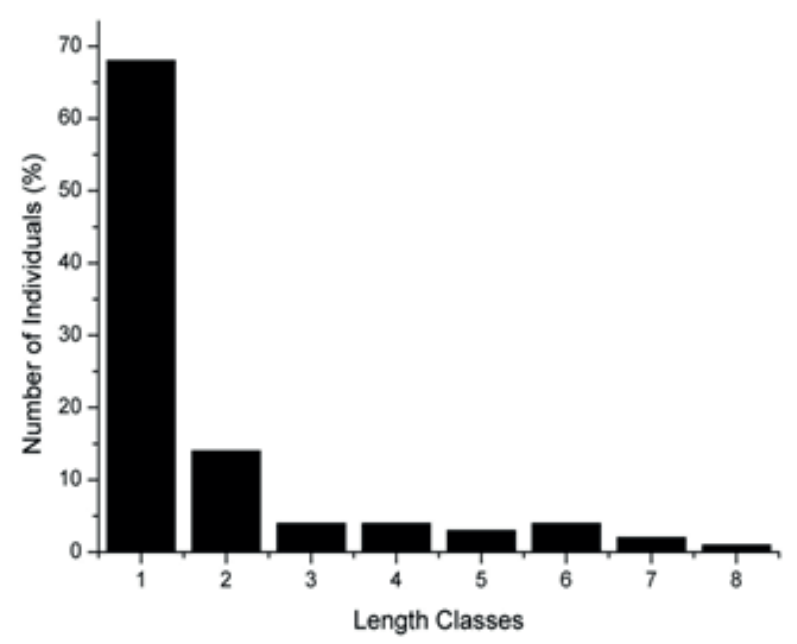

Fig. 2. Caudex length classification of a Cyathea praecincta population in an Atlantic Forest fragment in Northeastern Brazil.

been also reported for other Cyatheaceae species, including Sphaeropteris senilis (Klotzsch) R.M. Tryon (Ortega 1984), A. setosa (Schmitt \& Windisch 2005), C. delgadii (Schmitt \& Windisch 2007, Lehn \& Resende, 2007), C. spinulosa Wall. ex Hook. (Nagano \& Suzuki 2007) and A. firma (Baker) D. S. Conant (Mehltreter \& García-Franco 2008). The result features an exponential or reverse J-shaped pattern (Scolforo et al. 1998), which is frequently associated with favorable environment conditions for establishment of new individuals in plant populations or the history of reproduction of the species in the area.
The relation between caudex height and fertility found in the present $C$. praecincta population has been reported for other tree ferns (e.g. Schmitt \& Windisch 2005). The expression of this phenophase in plants in the first length class could be justified by the presence of vegetative reproduction in this population. As pointed by Schmitt \& Windisch (2005), some tree ferns have the ability to form new plants from underground branches (i.e. stoloniferous propagation). This condition was also observed by Lehn \& Rezende (2007) in C. delgadii, who reported a case where a $14 \mathrm{~cm}$ tall individual that had originated from vegetative reproduction was found producing fertile leaves. Thus, we emphasize the important role of vegetative reproduction, not only in the occupation of new spaces but also in the formation of fertile fronds in smaller individuals, as such branches may be small in size, but they have originated from older plants.

The low number of fertile plants in the C. praecincta population studied has been also reported in other tree ferns, such as C. delgadii (Schmitt \& Windisch 2007). This result indicates that the population remains in initial stages of expansion in areas that favor the establishment of C. praecincta.

In short, the clustered distribution, which points to preference for specific habitats, associated with intense fragmentation of NAF fragments, may have caused the low density observed in $C$. praecincta when compared to others studies. Despite such low density, the high number of individuals classified in the smaller length class ( 0 to $0.25 \mathrm{~m}$ ) may be an indication that the studied population is 
under expansion. This endorses the need for conservation of the study area and for reducing the risk of local extinction by disturbances such as excessive tree removal that could modify the optimal microhabitat of the species, further increasing the vulnerable status of $C$. praecincta.

\section{ACKNOWLEDGEMENTS}

The authors would like to thank the National Council for Scientific and Technological Development for providing research assistantships; the Trapiche Mill for allowing and supporting the development of this study in the Tauá Forest; and to everyone who directly or indirectly helped in carrying out this study. We thanks two reviewers to their contributions.

\section{REFERENCES}

Arens, N.C. \& Baracaldo, P.S. 1998. Distribution of tree ferns (Cyatheaceae) across a sucessional mosaic in an Andean cloud Forest, Narino, Colombia. American Fern Journal 88(2):60-71.

Clark, D.A. 1994. Plant Demography. In La Selva: ecology and natural history of a neotropical rainforest (A. Lucinda, I. Macdade, K.S. Bawa, H.A. Hespenheide \& G.S. Hartshorn, eds.). University of Chicago Press, Chicago, p. 90-105.

Climate-Data.Org. 2016. Clima: Sirinhaém. Available at $<$ http://pt.climatedata.org/location/4459/>. Access on 04 June 2016.

Dale, M.R.T. 1999. Spatial pattern analysis in plant ecology. Cambridge University, Cambridge. 326p.

Gurevitch, J., Scheiner, S.M. \& Fox, G. 2009. Ecologia vegetal. Artmed, Porto Alegre, v. 2, $574 \mathrm{p}$.

Jones, M.M., Rojas, P.O., Tuomisto, H. \& Clark, D.B. 2007. Environmental and neighbourhood effects on tree fern distributions in a neotropical lowland rain Forest. Journal of Vegetation Science 18(1):13-24

Krishna, U., Kanta, B.S., Dibyendu, A., Ratul, B. \& John, L.N. 2009. Regeneration ecology and population status of a critically endangered and endemic tree species (Ilex khasiana Purk.) in north-eastern India. Journal of Forestry Research 20(3): 223-228.

Lehn, C.R. \& Resende, U.M. 2007. Estrutura populacional e padrão de distribuição espatial de Cyathea delgadii Sternb.(Cyatheaceae) em uma Floresta Estacional Semidecidual no Brasil Central. Revista de Biociências 13(3-4):188-195.

Mehltreter, K. \& García-Franco, J.G. 2008. Leaf phenology and trunk growth of the deciduous tree fern Alsophila firma (Baker) D.S. Conant in a Lower montane Mexican forest. American Fern Journal 98(1):1-13.

Mallmann, I.V., Rocha, L.D. \& Schmitt, J.L. 2013. Padrão de distribuição espacial de quatro espécies de samambaia em três fragmentos de mata ciliar do rio Cadeia, RS, Brasil. Revista Brasileira de Biociências 11(2):139-144

Nagano, T. \& Suzuki, E. 2007. Leaf demography and growth pattern of the tree fern Cyathea spinulosa in Yakushima Island. Tropics 16(1):47-57.

Oliveira, P.E.A.M., Ribeiro, J.F., Gonzales, M.I. 1989. Estrutura e distribuição espacial de uma população de Kyelmeyera coriaceae Mart. de Cerrados de Brasília. Revista Brasileira de Botânica 12(2):39-47.

Ortega, F. 1984. Notas sobre la autoecología de Sphaeropteris senilis (KL) Tryon (Cyatheaceae) en el Parque Nacional el Avila - Venezuela. Pittieria 12:31-53.
Peacock, R.J., Downing, A., Brownsey, P. \& Cameron, D. 2013. Distribution, habitat preferences and population sizes of two threatened tree ferns, Cyathea cunninghamii and Cyathea $\mathrm{x}$ marcescens, in south-eastern Australia. Cunninghamia 13(1):1-24.

Peters, C.M. 1994. Sustainable Harvest of Non-Timber Plant Resources in Tropical Moist Forest: an ecological primer. Biodiversity Support Program, Washington. $45 \mathrm{p}$.

Pereira, A.F.N., Silva, I.A.A., Santiago, A.C.P. \& Barros, I.C.L. 2013. Richness, geographic distribution and ecological aspects of the fern community within the Murici Ecological Station in the state of Alagoas, Brazil. Acta Botanica Brasilica 27(4):788-800.

Perry, J.N., Bell, E.D., Smith, R.H. \& Woiwod, I.P. 1998. SADIE: software to measure and model spatial pattern. Aspects of Applied Biology 46:95-102.

Pietrobom, M.R. \& Barros, I.C.L. 2007. Pteridoflora do Engenho Água Azul, município de Timbaúba, Pernambuco, Brasil. Rodriguésia 58(1):85-94.

Ranta, P., Blom, T., Niemelã, J., Joensuu, E. \& Siitonen, M. 1998. The fragmented Atlantic rain Forest of Brazil: size, shape and distribution of Forest fragments. Biodiversity and Conservation 7(3):385-403.

Ricklefs, R.E. 2003. A economia da natureza. Guanabara Koogan, Rio de Janeiro. 503 p.

Rodrigues, A.S.L., Andelman, S.J., Bakarr, M.I., Boitani, L., Brooks, T.M., Cowling, R.M., Fishpool, L.D.C., Fonseca, G.A.B., Gaston, K.J., Hoffmann, M., Long, J.S., Marquet, P.A., Pilgrim, J.D., Pressey, R.L., Schipper, J., Sechrest, W., Stuart, S.N., Underhill, L.G., Walter, R.W., Watts, M.E.J. \& Yan, X. 2004. Effectiveness of the global protected area network in representing species diversity. Nature 428:640-643.

StatSoft. 2002. STATISTICA for Windows 6.0. StatSoft, Tulsa. Computer program manual.

Schmitt, J.L. \& Windisch, P.G. 2005. Aspectos ecológicos de Alsophila setosa Kaulf. (Cyatheaceae, Pteridophyta) no Rio Grande do Sul, Brasil. Acta Botanica Brasilica 19(4):859-865.

2007. Estrutura populacional e desenvolvimento da fase esporofitica de Cyathea delgadii Sternb. (Cyatheaceae, Monilophyta) no sul do Brasil. Acta Botanica Brasilica 21(3):731-740.

Scolforo, J.R.S., Pulz, F.A. \& Melo, J.M. 1998. Modelagem da produção, idade das florestas nativas, distribuição espacial das espécies e a análise estrutural. In Manejo Florestal (J.R.S. Scolforo, ed.). Universidade Federal de Alagoas/Fundação de Apoio ao Ensino, Pesquisa e Extensão, Lavras, p. 189-246.

Silva, I.A.A., Pereira, A.F.N. \& Barros, I.C.L. 2011. Edge effects on fern community in an Atlantic Forest remnant of Rio Formoso, PE, Brazil. Brazilian Journal of Biology 71(2):421-430.

Tanner, E.V.J. 1983. Leaf demography and growth of tree fern Cyathea pubescens Mett. Ex Kuhn in Jamaica. Botanical Journal of the Linnean Society 87(3):213-227.

Uchôa-Neto, C.A.M. 2002. Integridade, grau de implementação e viabilidade das unidades de conservação de proteção integral na floresta Atlântica de Pernambuco. Dissertação 45 f., Universidade Federal de Pernambuco, Recife.

Weigand, A. \& Lehnert, M. 2016. The scaly tree ferns (CyatheaceaePolypodiopsida) of Brazil. Acta Botanica Brasilica 30(3):1-15.

Windisch, P.G. \& Santiago, A.C.P. 2015. Cyatheaceae. In Lista de Espécies da Flora do Brasil. Available at $<$ http://floradobrasil.jbrj.gov.br/jabot/ floradobrasil/FB90850 > Access on 06. January.2016.

Wolf, P.G., Schneider, H. \& Ranker, T. 2001. Geographic distributions of homosporous ferns: does dispersal obscure evidence of vicariance? Journal of Biogeography 28(2):263-270.

Young, A., Boyle, T. \& Brown, T. 1996. The population genetics consequences of habitat fragmentation for plants. Tree 11(10):413418. 